\title{
EFFECT OF PHOSPHORUS FERTILIZATION, FOLIAR APPLICATION WITH SEAWEED EXTRACTS AND MICRONUTRIENTS ON VEGETATIVE GROWTH AND DRY SEED YIELD OF OKRA (ABELMOSCHUS ESCULENTUS L.)
}

\author{
A. Y. Ismail and A.A.M. Fayed \\ (1) Vegetable Crops Seed Production and Technology Department, \\ (2) Horticulture Research Institute, Agriculture Research Centre, Cairo, Egypt
}

Received: Aug. 21, 2021

Accepted: Aug. 31, 2021

ABSTRACT: This field trial was carried out at Sidi Salem district, Kafr El-Sheikh Governorate, Egypt during the two summer seasons of 2017 and 2018 on okra plants (Abelmoschus esculentus L.) cv. Baladi to study the beneficial effects of different levels of phosphorus fertilizer i.e. $\left(0,30\right.$ and $\left.45 \mathrm{~kg} \mathrm{P}_{2} \mathrm{O}_{5}\right)$ with micronutrients; Fe, $\mathrm{Zn}$ and $\mathrm{Mn}$ at $1 \mathrm{~g} / \mathrm{L}$, or seaweed extract at $3 \mathrm{~cm} / \mathrm{L}$ on plant vegetative growth, dry seed yield and nutrient uptake of okra. All studied treatments were arranged in a split plot design with three replicates. The results showed that adding phosphorus fertilizer at $30 \mathrm{~kg} \mathrm{P}_{2} \mathrm{O}_{5}$ with seaweed extract at $3 \mathrm{~cm} / \mathrm{L}$ to okra plants produced significantly higher values of vegetative growth, total dry seed yield and chemical composition of okra plants followed by phosphorus fertilizer at $30 \mathrm{~kg} \mathrm{P}_{2} \mathrm{O}_{5}$ with $\mathrm{Fe}$ at the rate of $1 \mathrm{~g} / \mathrm{L}$. This shows a significant improvement for okra cultivation by application of phosphorus fertilizer combined with seaweed extract or micronutrients

Key words: Okra, phosphorus fertilizer, seaweed extract, Fe, Mn, Zn, growth, dry seed yield, seed quality

\section{INTRODUCTION}

Okra (Abelmoschus esculentus L.) is an important fruit vegetable crop of the tropical and subtropical regions of the world. In Egypt, it is one of the most popular vegetables and considered a valuable source of vitamins and minerals with good medicinal properties. It has been grown for its edible green pods which can be used as fresh, canned, frozen or dried food. The seed is the prime factor that determines the quantitative and qualitative characteristics of the crop that is going to be harvested later on. Therefore; more attention must be directed towards increasing seed yield with good quality. Successful production of okra seed is conditional to certain agricultural practices.

Algae extract as a new bio-fertilizer containing minerals nutrition and some growth regulators, polyamines, natural enzymes, carbohydrates, proteins and vitamins which applied to improve vegetative growth and yield (Abd ElMoniem and Abd- Allah, 2008).

Algae are classified into three groups; namely green, brown and red based on their pigments. Different forms of algae have been reported to produce beneficial effects on some vegetable crops (Abd EIMawgoud et al., 2010). They are a natural bioactive materials rich in minerals, protein, lipids, carbohydrates, vitamins and microelements (Co, B, Mo, Zn, Cu). In addition, seaweed fertilizer is a unique combination of $N, P, K$, trace elements and simple sugar that are in dissolved forms that are easily absorbed through roots and leaves besides releasing trace elements bound to the soil (Chapman and Chapman, 1980) and it is safe to human, animals and the environment (Sathya et al., 2010). 
Phosphorus is an element key in the formation of high energy compounds, such as AMP, ADP and ATP, which play an essential role in photosynthesis and respiration. It is a vital component of nucleic acids and phospholipids. Plants take up phosphorus in the inorganic form, mainly as the orthophosphate $\mathrm{H}_{2} \mathrm{PO}_{4}$ ion. Phosphorus supports early phase of crop development, synchronizes the germination process and leading to enhance the final yield, especially in $P$ deficient soil (Asgedom and Becker, 2001 and Arif et al., 2005). It increases crop resistance to diseases. In contrast to $N$, deficiency symptoms of $P$ most often, occur in seedlings and young plants. Since $P$ is mobile within the plant, symptoms appear on the lower leaves/parts of the plants (Khalil, 2006).

Micro nutrients are required for optimal growth (Ahmad et al., 2011 and Ahmad et al., 2009) specifically six micronutrients ( $\mathrm{Zn}, \mathrm{B}, \mathrm{Fe}, \mathrm{Cu}, \mathrm{Mo}, \mathrm{Mn})$ play vital roles in plant physiology and biochemical processes (Putra et al., 2012 and Rab and Haqm, 2012). Zinc influence on basic plant life processes, nitrogen metabolism, uptake of nitrogen and protein quality, photosynthesis, chlorophyll synthesis, soil is inaccessible to plant roots if carbon anhydrate activity; resistance to a biotic and biotic stresses, protection against oxidative damage Cakmak (2008), membrane integrity and phytochrome activities Shkolnik (1984).

Iron $(\mathrm{Fe})$ is an important micronutrient for chlorophyll formation, photosynthesis, enzyme systems and respiration of plants (Havlin et al.,1999). Sometimes $\mathrm{Fe}$ application might cause nutritional disorder by its antagonistic effect with other cationic micronutrients, in particular with $\mathrm{Mn}$ (Ghasemi and Ronaghi, 2008). Besides, application of these nutrients in, soil is inaccessible to plant roots if soil pH is more (Rashid and Ryan 2004) and biotic. Foliar spray of micronutrients is more effective to control deficiency problem than soil application (Torun et al., 2001).

This study aimed to investigate the influence of different phosphorus fertilizer levels and foliar applications of micronutrients or seaweed extract on vegetative growth, dry seed yield, seed quality and chemical constituents of okra plants.

\section{MATERIALS AND METHODS}

This field trials were conducted during the two summer seasons of 2017 and 2018 at Sidi Salem district, Kafr El-Sheikh Governorate, Egypt on okra (Abelmoschus esculentus L.) Baladi cv. Sample of the soil was taken to determine the physical and chemical properties according to (Black, 1965 and Page et al., 1982). Chemical analysis is shown in Table (1).

The plot area was $11.2 \mathrm{~m}^{2}$ and included 4 ridges, each ridge of $0.7 \mathrm{~cm}$ width and $4 \mathrm{~m}$ length. Seeds of okra were sown at the first week of April in both seasons in hills on one side of ridges at $25 \mathrm{~cm}$ apart.

Table (1): Chemical analysis of soil used in the present study

\begin{tabular}{|c|c|c|c|c|c|c|c|c|c|c|c|c|c|c|c|c|c|}
\hline \multirow{2}{*}{ T⿱ } & \multirow{2}{*}{ 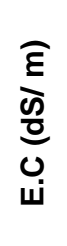 } & \multirow{2}{*}{$\sum_{0}$} & \multicolumn{4}{|c|}{$\begin{array}{l}\text { Soluble cations } \\
\text { (M/L) }\end{array}$} & \multicolumn{4}{|c|}{$\begin{array}{l}\text { Soluble anions } \\
(M / L)\end{array}$} & \multicolumn{3}{|c|}{$\begin{array}{l}\text { Macro } \\
\text { elements } \\
(p p m)\end{array}$} & \multicolumn{4}{|c|}{$\begin{array}{l}\text { Micro elements } \\
\quad(\mathrm{ppm})\end{array}$} \\
\hline & & & \% & $\stackrel{7}{\Sigma}$ & $\stackrel{+\pi}{z}$ & \pm & ָั & $\begin{array}{l}3 \\
\text { '0 } \\
\text { ำ }\end{array}$ & ত̃ & 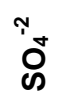 & z & a & $\underline{Y}$ & ๗ั & $\overrightarrow{0}$ & $\mathfrak{N}$ & $\stackrel{\Sigma}{\Sigma}$ \\
\hline 25 & 2.31 & 2.19 & 5.34 & 4.12 & 12.3 & 0.16 & - & 3.48 & 14.2 & 4.23 & 81 & 6.3 & 58.8 & 3.0 & 6.8 & 2.18 & 2.17 \\
\hline
\end{tabular}


The treatments were arranged in a split plot design as follows:

I. The main plots were assigned in tow levels of phosphorus fertilizer (calcium super phosphate, 15.5\% $\mathrm{P}_{2} \mathrm{O}_{5}$ ) beside the control was added as soil application during soil preparation as follows:

A- $30 \mathrm{Kg} \mathrm{P}_{2} \mathrm{O}_{5} / \mathrm{fed}$. (200kg/fed. calcium super phosphate, $15.5 \% \mathrm{P}_{2} \mathrm{O}_{5}$ )

B- $45 \mathrm{~kg} \mathrm{P}_{2} \mathrm{O}_{5} / \mathrm{fed}$. (300kg/fed. calcium super phosphate, $15.5 \% \mathrm{P}_{2} \mathrm{O}_{5}$ )

II. The sub plots were assigned for four foliar applications beside the control (without spraying) that applied at three times (after 30, 45 and 60 days from sowing date) as follows:

A- Algae extract at $3 \mathrm{~cm} / \mathrm{L}$.

B- Fe at $1 \mathrm{~g} / \mathrm{L}$.

C- Mn at $1 \mathrm{~g} / \mathrm{L}$.

D- $\mathrm{Zn}$ at $1 \mathrm{~g} / \mathrm{L}$.

Algae extract strain; Spirulina platensis was obtained from El-Natron valley, Algal Biotechnology Unit, National Research Center (N.R.C). The extract contains $40-60 \%$ of Algal biomass. Algae extract was analyzed before spraying and the algal chemical analysis is shown in Table (2).

The sources of microelements of $\mathrm{Fe}$, $\mathrm{Mn}$ and $\mathrm{Zn}$ were Fe-chelated (12\%), Mnchelated (12\%) and Zn-chelated (12\%), respectively. All required agricultural managements of okra production such as irrigation, fertilization and pest control of studied area were followed according to the recommendations of Egyptian Ministry of Agriculture.

The following data were recorded in the present study.

1- Vegetative growth characteristics
At flowering stage (after $\mathbf{5 0}$ days from sowing date), five plants were randomly taken from each experimental plot to evaluate vegetative growth characteristics i.e. plant height (cm), number of leaves/plant, leaf area $\left(\mathrm{cm}^{2}\right)$ and the total fresh as well as dry weight/plant (g). The plant organs of foliage (leaves, stems and branches) were dried at $70 \mathrm{C}^{\circ}$ till constant weight and then the dry weight/plant was recorded.

\section{2- Dry seed yield and its components}

At full seed ripening stage (after 120 days from sowing date), a random sample of 5 plants were taken from each plot and dry pods were picked to estimate dry seed yield components i.e. number of dry pods/plant, number of dry seeds/pod, seed index (100 seeds weight) and dry seed yield, while the total dry seed yield (kg/fed) was calculated through dry seed yield / plot.

\section{3- Chemical composition of dry seeds}

A sample of $0.2 \mathrm{~g}$ from fine powder of dry seeds was digested in a mixture of sulphuric and perchloric acids according to Piper (1947) to estimate N, P, K and protein (\%) in dry seeds. Total nitrogen (\%) was determined by using the modified "Micro-Kjeldahl" method apparatus of Parnas and Wagner as described by Pregl (1945). Phosphorus (\%) was estimated spectrophotometrically in dry seeds according to the method described by Murphy and Riley (1962) as modified by John (1970). Potassium was determined by flame-photometrically as described by Brown and Lilleland (1946). Iron (Fe) and Zinc (Zn) were extracted using DTPA, (Lindsay and Norvell, 1978).

Table (2): Algae extract analysis

\begin{tabular}{|l|c|c|c|c|c|c|c|c|c|}
\hline Element & $\mathrm{N} \%$ & $\mathbf{P} \%$ & $\mathrm{~K} \%$ & $\mathbf{M g} \%$ & $\mathbf{C a} \%$ & $\begin{array}{c}\mathrm{Fe} \\
(\mathrm{ppm})\end{array}$ & $\begin{array}{c}\mathrm{Zn} \\
(\mathbf{p p m})\end{array}$ & $\begin{array}{c}\mathrm{Mn} \\
(\mathbf{p p m})\end{array}$ & $\begin{array}{c}\mathrm{Cu} \\
(\mathbf{p p m})\end{array}$ \\
\hline Concentration & $\mathbf{1 3 . 3}$ & $\mathbf{2 . 2 2}$ & $\mathbf{2 . 1 3}$ & $\mathbf{0 . 1 1}$ & $\mathbf{0 . 2 3}$ & $\mathbf{4 6 4 4}$ & $\mathbf{2 1}$ & $\mathbf{9 5 4}$ & $\mathbf{1 3 0 0}$ \\
\hline
\end{tabular}




\section{4- Seed germination test}

Okra dry seeds were treated with fungicide (Topsin M 70\%wp), then were put it in filter paper inside germination incubator at $25 \mathrm{C}^{\circ}$. Germination experiment was conducted to test i.e. germination $\%$ and germination rate as follows:

Germination $\%=$ No. of germinated seeds $\times 100$ No. of sown seeds

Germination rate $=$

$(\mathrm{G} 1 \times \mathrm{N} 1)+(\mathrm{G} 2 \times \mathrm{N} 2)+$ (Gn x Nn)

G1 + G2 ..Gn

Where: $\mathbf{G}=$ Number of germinated seeds in certain day, $\mathrm{N}=$ Number of this certain day

\section{5- Statistical analysis}

The obtained data were subjected to the statistical analysis of variance and treatment means were compared according to the Less Significant Differences (L.S.D. at $0.05 \%$ as described by Snedecor and Cochran (1990).

\section{RESULTS AND DISCUSSION}

\section{I- Vegetative growth parameters}

Results in Table $3 a$ showed that phosphorus fertilizer at $30 \mathrm{~kg} \quad\left(\mathrm{P}_{2} \mathrm{O}_{5}\right)$ increased significantly all vegetative growth parameters (plant height, number of leaves and branches, leaf area as well as fresh and dry weight/plant). However, increasing P-application at $45 \mathrm{~kg} \mathrm{P}_{2} \mathrm{O}_{5} / \mathrm{fed}$ did not significantly increase any growth parameters in both seasons. Such increment in plant growth by $P$ application could be referred to the role of $P$ on root proliferation and growth (Tisdale and Nelson, 1975 and Ohlrogge, 1962) as well as its effect on cell energy through organic phosphate compounds; ADP and ATP. This favorable role of Papplication level vegetative growth parameters are in agreement with those results obtained by, Uddin et al., (2014) which illustrated adding phosphorus on okra plants with 80 or $90 \mathrm{~kg} \mathrm{P}_{2} \mathrm{O}_{5} / \mathrm{ha}$. They found these rates significantly increased number of leaves and branches/plant. Also, El-Waraky (2014) found that increasing applied phosphorus fertilizer rate up to $45 \mathrm{~kg} \mathrm{P}_{2} \mathrm{O}_{5} / \mathrm{fed}$ gave the highest values of plant height, number of leaves and branches/pant of okra plants. Likewise, Ahmed et al., (2015) mentioned that application of $75 \mathrm{~kg} \mathrm{P}_{2} \mathrm{O}_{5} / \mathrm{fed}$ to okra plants obtained the highest values of plant growth.

Foliar application of seaweed extract at the rate of $(3 \mathrm{~cm} / \mathrm{L})$ was the most effective treatment on growth parameters, as compared with the other treatments or the control, during the both seasons (Table 3a). The enhancement effect of algae extract on okra plants growth may be attributed to the auxin content of the algae extract which has an effective role in cell division and enlargement that leads to increase the shoot growth (Lopez et al., 2008), number of leaves and plant dry weight (Gollan and Wright, 2006) where it is a rich source of potassium and contains considerable amounts of $\mathrm{Ca}, \mathrm{Cu}, \mathrm{Fe}, \mathrm{Mg}$, $\mathrm{Mn}, \mathrm{P}$ and $\mathrm{Zn}$ (Marrez et al., 2014). It also contains macronutrients ( $N, P$ and $K$ ) which are very essential for growth and development of the plant (Chapman and Chapman, 1980 and Attememe, 2009). These obtained results agreed with those reported by Tensingh et al., (2017) reported that algae extract application significantly promoted the growth characters of Okra. Ismail (2016) on common bean showed that adding algae extract at $5 \mathrm{~cm} / \mathrm{L}$ resulted in the highest values of growth compared with untreated plants. Furthermore, similar results were found by Mohamed et al., (2016) on chickpea, Abbas (2013) on Phaseolus vulgaris, Anna et al., (2013) on common bean, Dalia and Sabreen (2014) on pea and Khattab et al., (2015) on faba bean. Vyomendra and Kumar (2016) 
mentioned that algae play an important role on growth characters such as stem length, fresh and dry weight/plant.

Concerning interaction effects between phosphorus fertilizer levels and spraying treatments on vegetative growth characteristics, data in Table (3b) pointed out that higher vegetative growth parameters were obtained with the most superior treatment $30 \mathrm{~kg} \mathrm{P}_{2} \mathrm{O}_{5} / \mathrm{fed}$ with seaweed extract at the rate of $3 \mathrm{~cm} / \mathrm{L}$ followed by $30 \mathrm{~kg} \mathrm{P}_{2} \mathrm{O}_{5} / \mathrm{fed}$ with $\mathrm{Fe}$ at the rate of $1 \mathrm{gm} / \mathrm{L}$ as compared with the other tested treatments. The increment in growth parameter may be due to that Algae extract containing minerals nutrition, some growth regulators, polyamines, proteins and vitamins applied to improve vegetative growth (Abd El- Moniem and Abd- Allah, 2008), and the importance role of phosphorus is an element key in the formation of high energy compounds, which play an essential role in photosynthesis which improve vegetative growth (Asgedom and Becker, 2001; Arif et al., 2005).

\section{2- Dry seed yield and its components}

Results of dry seeds and its components were presented in Table (4a). These indicated that, all dry seed yield components (number of dry pods/plant, number of dry seeds/pod, seed index and dry seed yield) were significantly improved by adding $P$ fertilizer level from at $30 \mathrm{~kg} \mathrm{P}_{2} \mathrm{O}_{5} / \mathrm{fed}$. However, increasing $P$-application level up to $45 \mathrm{~kg}_{2} \mathrm{O}_{5} / \mathrm{fed}$ did not increase dry seed yield components as shown in both seasons. The favorable effect of increasing phosphorus application level on dry seed yield is mainly due to its effect on improving plant growth, minerals uptake as shown in Table 5a which consequently improved dry seed yield and its components. The obtained results are in harmony with those of Amjad et al. (2001), Chattopahyay et al. (2001), Patton et al. (2002), Singh (2002),
El-Shaikh (2005), El-Shaikh and Mohammed (2009) who observed significant increases in seed yield with phosphorus application to okra plants. In the same line, Sajid et al., (2012), Uddin et al., (2014) El-Waraky (2014) and Ahmed et al., (2015) on okra plants.

Dry seed yield could be considered to be the mirror of all growth features. The results are given in the same Table (4a) cleared that spraying plants with $3 \mathrm{~cm} / \mathrm{L}$ seaweed extract gave the highest dry seed yield components followed by foliar treatment of $1 \mathrm{~g} / \mathrm{L} \mathrm{Fe}$ as compared with unsprayed plants. The obtained resulted may be attributed to that the importance effects of seaweed extract is a unique combination of $N, P, K$, trace elements and simple sugar that are in dissolved forms that are easily absorbed through roots and leaves besides releasing trace elements bound to the soil (Chapman and Chapman, 1980) and it is safe to human, animals and the environment (Sathya et al., 2010). However, $\mathrm{Fe}$ is an important micronutrient for chlorophyll formation, photosynthesis, enzyme systems and respiration of plants (Havlin et al., 1999).

The obtained results of the favorable effect of algae extract on yield and its components were in harmony with reported by Tensingh et al., (2017) reported that algae extract application significantly promoted the okra dry seed yield characters. Also, Anna et al., (2013) and Latique et al., (2013) on common bean revealed that foliar application with seaweed gave the highest dry seed yield characters i.e. number of seeds/pod, seed index and shell out. In the same line, Dalia and Sabreen (2014) cowpea plants, Ismail (2016) on common bean. Vyomendra and Kumar (2016) illustrated that spraying cowpea plants with algae improved dry seed yield components (number of dry seeds/pod, 100 seeds wt. and dry seed yield/ha). 


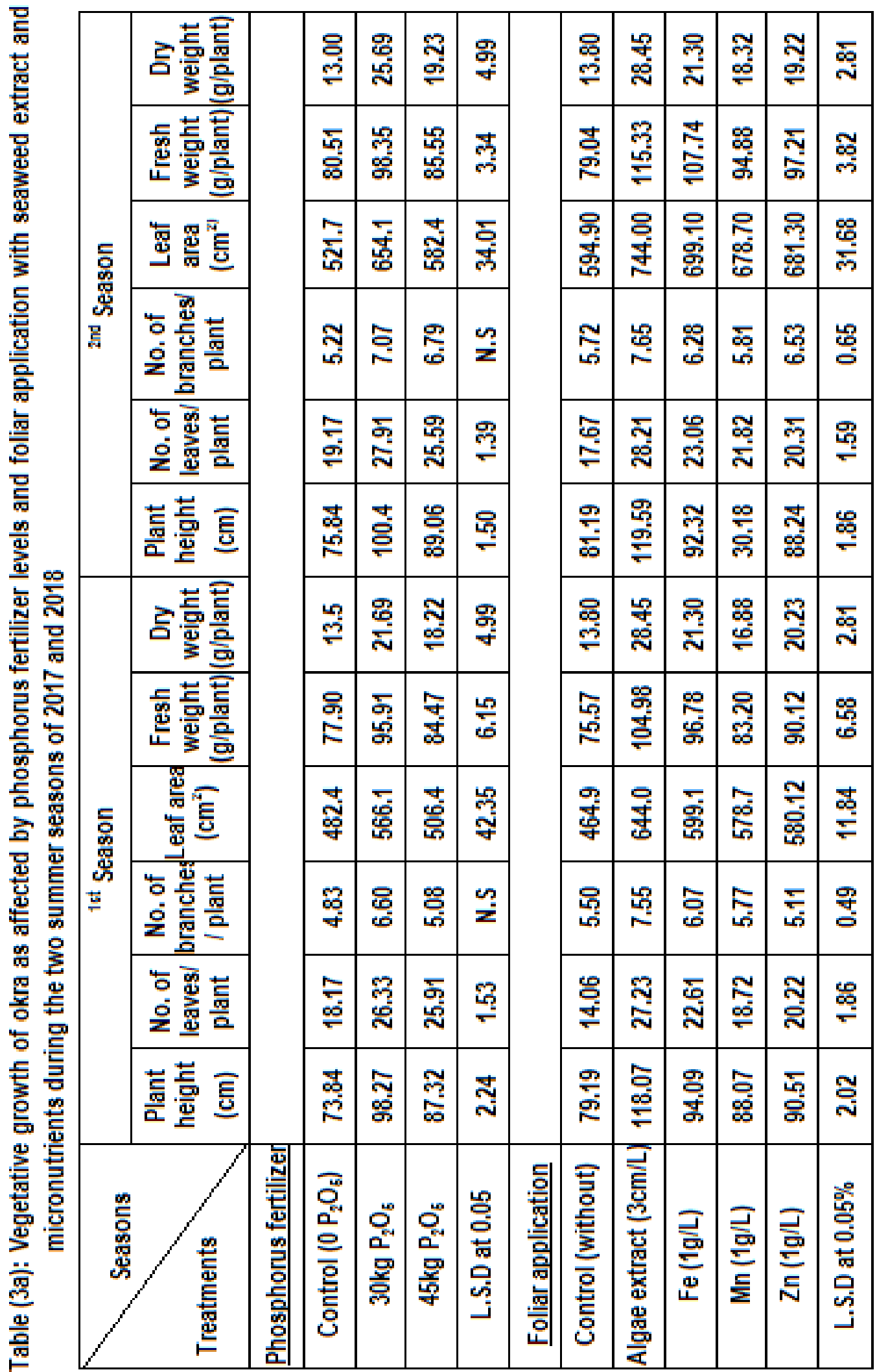




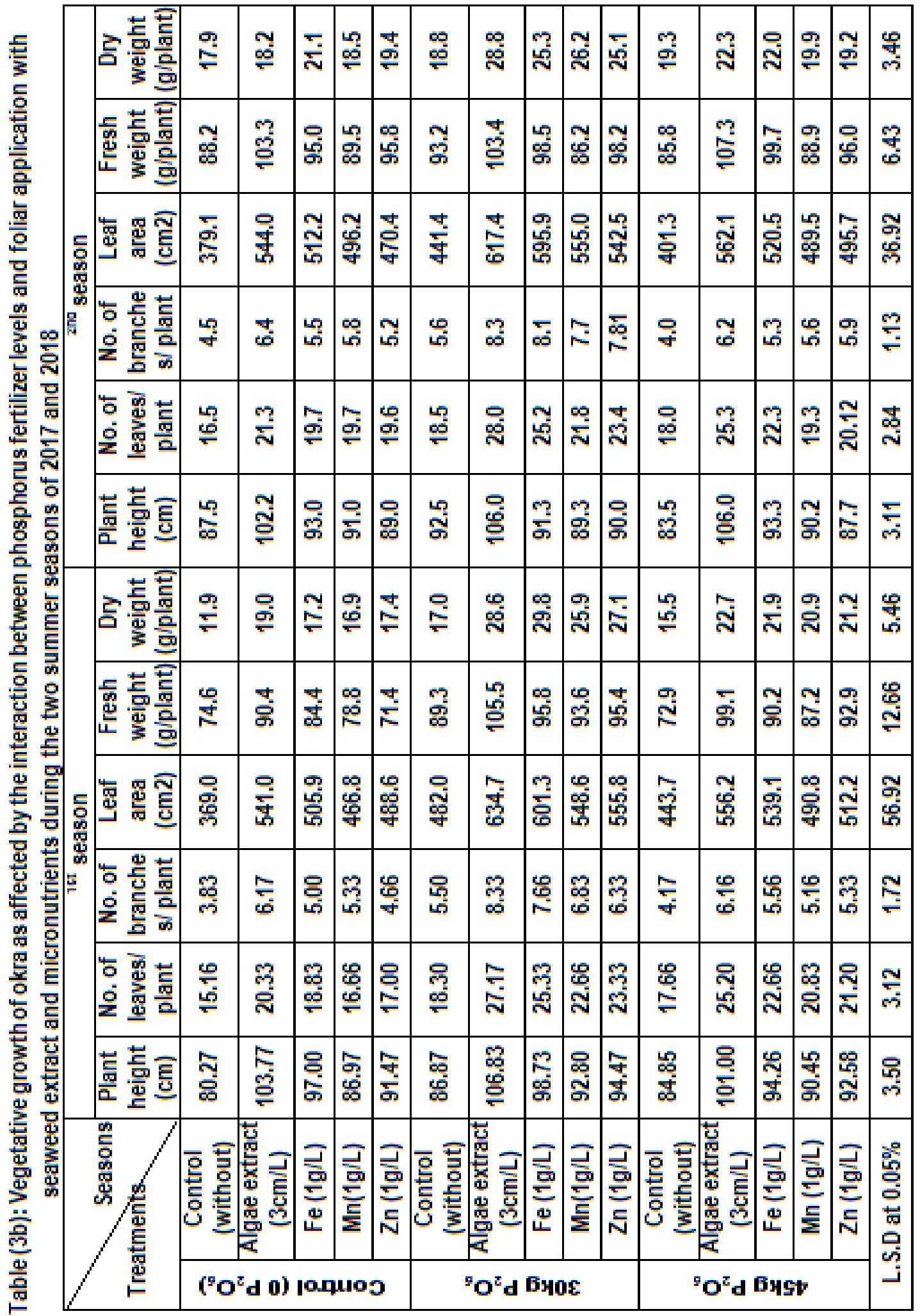




\begin{tabular}{|c|c|c|c|c|c|c|c|c|c|c|c|c|c|}
\hline \multirow{5}{*}{ 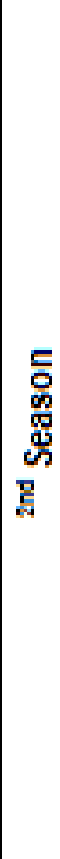 } & 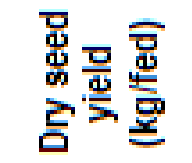 & & กํำ & 苑 & 管 & $\begin{array}{l}\text { ọ } \\
\text { ơ }\end{array}$ & & $\stackrel{2}{2}$ & 峁 & 容 & 范 & $\frac{\infty}{\dot{q}}$ & 尔 \\
\hline & 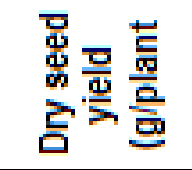 & & กี & $\begin{array}{l}\text { 品 } \\
\text { of }\end{array}$ & ন্ষু & Бొ & & $\begin{array}{l}\text { గ్ర } \\
\text { o }\end{array}$ & 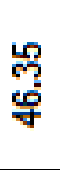 & స్త్ర & స్ & సู & 芯 \\
\hline & 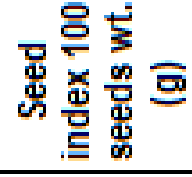 & & 芯 & $\stackrel{\text { 岕 }}{\rightleftarrows}$ & 芯 & 䒚 & & $\underset{N}{\text { 守 }}$ & $\stackrel{ }{\frac{2}{2}}$ & $\begin{array}{l}\text { @̊ } \\
\stackrel{0}{0}\end{array}$ & స్ & స్ & $\overleftarrow{i}$ \\
\hline & 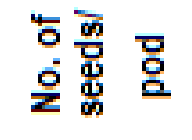 & & స్ & 管 & 芯 & 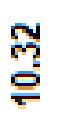 & & $\begin{array}{l}\text { 号 } \\
\text { గ్రై }\end{array}$ & 衣 & చొ & ষ্ঠ & 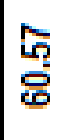 & $\simeq$ \\
\hline & 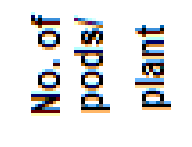 & & $\frac{ \pm}{\sigma}$ & $\underset{\infty}{\stackrel{2}{\infty}}$ & $\begin{array}{l}\stackrel{2}{\sim} \\
\underset{\leftarrow}{\leftarrow}\end{array}$ & 㫕 & & 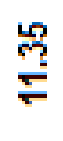 & $\begin{array}{l}\underset{\Xi}{0} \\
\infty \\
\infty\end{array}$ & 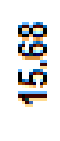 & 守 & ָึ & 5 \\
\hline & 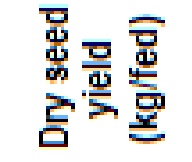 & & 管 & $\stackrel{?}{\stackrel{?}{\longleftarrow}}$ & 管 & 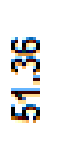 & & 芯 & 誉 & 总 & ঙ্লু & 莕 & 1 \\
\hline & 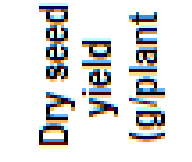 & & 芯 & 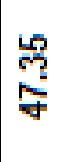 & స్ & ָָ & & 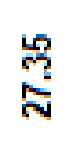 & $\begin{array}{l}\text { 吕 } \\
\text { 胞 }\end{array}$ & స్ల & 志 & 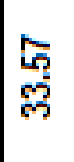 & $?$ \\
\hline 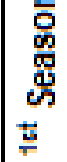 & 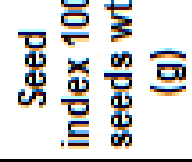 & & 鸷 & 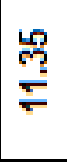 & స్ & స్ & & $\underset{N}{N}$ & $\stackrel{\text { 巳q }}{=}$ & స్ㅁㅇㅁ & ळ. & $\begin{array}{l}50 \\
\infty\end{array}$ & 18 \\
\hline & 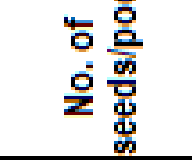 & & 亗 & $\underset{\Gamma}{\tilde{r}}$ & 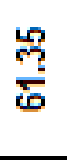 & 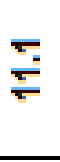 & & $\begin{array}{l}\text { ర్రి } \\
\text { గ్ }\end{array}$ & న్ & 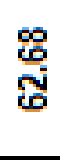 & స్. & 导 & 胥 \\
\hline & 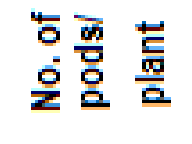 & & $\underset{\infty}{\mp}$ & $\stackrel{\stackrel{2}{?}}{\stackrel{2}{\leftarrow}}$ & 先 & చొ & & ્ㅗㅇ & 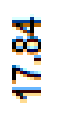 & $\begin{array}{l}\text { 题 } \\
\stackrel{+}{\leftarrow}\end{array}$ & ڤึ้ & ֻู & స్ \\
\hline & & 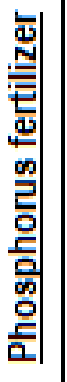 & 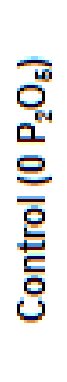 & 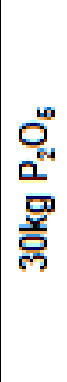 & 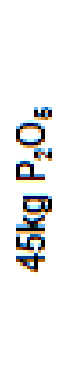 & 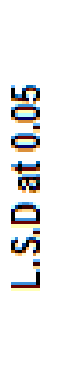 & 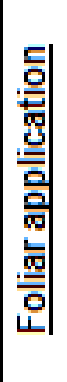 & 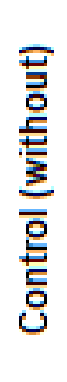 & 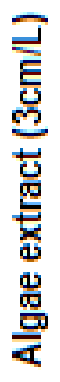 & 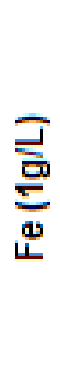 & 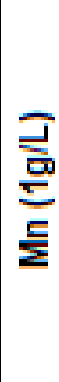 & כָ & 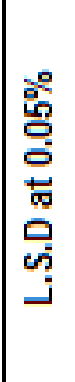 \\
\hline
\end{tabular}


Concerning to the interaction, the results in Table (4b) further proved that the highest dry seed yield with the best components were obtained by fertilizing okra plants with $30 \mathrm{~kg} \quad \mathrm{P}_{2} \mathrm{O}_{5} / \mathrm{fed}$ and spraying with $3 \mathrm{~cm} / \mathrm{L}$ seaweed extract. That was the best interaction treatment which produced the highest means values over the other interactions treatments which provided the best characters.

\section{3- Chemical composition of dry seeds}

The effect of different levels of phosphorus fertilizer i.e. $(0,30$ and $45 \mathrm{~kg}$ $\mathrm{P}_{2} \mathrm{O}_{5}$ ) on okra chemical composition of dry seeds are presented in Table (5a). Data illustrated that macro elements; N, $P$ and $K$ and micro elements ( $F e, ~ Z n$ and $\mathrm{Mn}$ ) of dry seeds were significantly higher by increasing P-fertilizer level at $30 \mathrm{~kg} \mathrm{P}_{2} \mathrm{O}_{5} / \mathrm{fed}$. Whereas, increasing $\mathrm{P}$ application level up to $45 \mathrm{~kg} \mathrm{P}_{2} \mathrm{O}_{5} / \mathrm{fed}$ did not increase chemical composition of dry seeds in both seasons. Such increment in okra dry seed chemical composition by adding phosphorus could be referred to the role of $\mathbf{P}$ on root proliferation and growth (Tisdale and Nelson, 1975 and Ohlrogge, 1962) as well as its effect on cell energy through organic phosphate compounds; ADP and ATP. This favorable role of $P$ - application level vegetative growth parameters and consequently enhances elements of okra dry seeds. These results coincided with those reported by Uddin et al., (2014). Also, Ahmed et al., (2015) mentioned that application of $75 \mathrm{~kg} \mathrm{P}_{2} \mathrm{O}_{5} / \mathrm{fed}$ gave higher values of $\mathrm{N}, \mathrm{P}$ and $\mathrm{K}$ in okra dry seeds.

As for the effect of foliar application with algae extract and micronutrients, data in Table (5a) showed that that the highest values of elements content (\%) in dry seeds were observed when okra plants sprayed by seaweed extract at the rate of $3 \mathrm{~cm} / \mathrm{L}$ followed by $\mathrm{Fe}$ at the rate 1 $\mathrm{gm} / \mathrm{L}$ as compared with the other treatments or the control. These results are consistent with those of Hegazi et al., (2010) on common bean they found that using of algae as bio-fertilizer greatly enhances $N, P$ and $K$ content in seeds. Also, Abbas (2013) on bean cv. Giza 3 mentioned that the algae extraction treatment recorded the highest values of phosphorus compared with untreated plants. Moreover, Anna et al., (2013) and Latique et al., (2013) on common bean, Dalia and Sabreen (2014) on pea, Khattab et al., (2015) on faba bean and Vyomendra and Kumar (2016) on Vigna radiata all revealed similar results.

Concerning to the interaction effects among different phosphorus fertilizer levels and foliar application treatments on chemical composition of okra dry seeds, the results presented in Table (5b) further proved that the highest chemical composition of okra dry seed expressed as, N, P, K, Fe, $\mathrm{Zn}$ and $\mathrm{Mn}$ were obtained when okra plants fertilized by phosphorus at the rate $30 \mathrm{~kg} \mathrm{P}_{2} \mathrm{O}_{5} /$ fed and seaweed extract at the rate of $3 \mathrm{~cm} / \mathrm{L}$. These treatments were the best interactions, whichproduced the highest means values for most of characters.

\section{4- Seed germination tests}

Seed germination tests as affected by phosphorus fertilizer levels on okra i.e. seed germination ratio (\%), germination rate (days), and sprout length $(\mathrm{cm})$ are shown in Table (6a). Such data revealed that increasing P-fertilizer level led to a significant increase in seed germination ratio, germination rate, and sprout length at $30 \mathrm{~kg} \mathrm{P}_{2} \mathrm{O}_{5} / \mathrm{fed}$ in both seasons. However, heavy application of $P$ up to $45 \mathrm{~kg} \quad \mathrm{P}_{2} \mathrm{O}_{5} / \mathrm{fed}$ significantly decreased seed germination, as compared with that of plants supplied with $30 \mathrm{~kg} \mathrm{P}_{2} \mathrm{O}_{5} /$ fed in both seasons. These results coincided with those reported by El-Waraky (2014) Sajid et al., (2012) on okra. 


\begin{tabular}{|c|c|c|c|c|c|c|c|c|c|c|c|c|c|c|c|c|c|}
\hline & 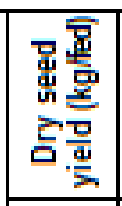 & 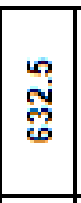 & 岕 & $\frac{m}{\Sigma}$ & $\underset{j}{\stackrel{\infty}{*}}$ & 嗃 & ¿্ं & 苍 & \begin{tabular}{|l|}
$\omega$ \\
$\tilde{\infty}$ \\
$\infty$ \\
$\infty$
\end{tabular} & 㖣 & $\stackrel{n}{\stackrel{n}{L}}$ & $\begin{array}{l}\overrightarrow{0} \\
\text { o } \\
\text { gे }\end{array}$ & ㄲ. & ঙุ. & $\stackrel{-}{\stackrel{亠}{\infty}}$ & 定 & พั \\
\hline & 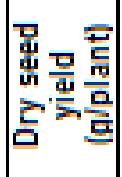 & $\begin{array}{l}\infty \\
\infty \\
\tilde{~}\end{array}$ & 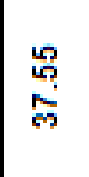 & 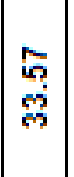 & స్ & న్ & $\underset{\sim}{\mp}$ & $\begin{array}{l}\bar{\delta} \\
\dot{\varphi} \\
q\end{array}$ & 总 & $\bar{E}$ & $\stackrel{m}{\dot{m}}$ & $\begin{array}{l}\text { م } \\
\text { N }\end{array}$ & 足 & ָָ & $\begin{array}{l}\mathscr{0} \\
\tilde{ల} \\
\tilde{ల}\end{array}$ & $\underset{\text { ले }}{\bar{\rho}}$ & $\overline{\mathrm{N}}$ \\
\hline 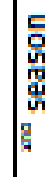 & 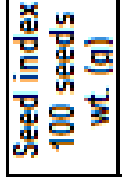 & $\underset{\Sigma}{\Sigma}$ & $\begin{array}{l}\tilde{\infty} \\
\sigma\end{array}$ & $\left|\begin{array}{c|}\overrightarrow{0} \\
\vdots \\
\infty\end{array}\right|$ & $\underset{\infty}{\infty}$ & $\frac{\nabla}{\infty}$ & ભొ & 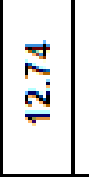 & $\begin{array}{l}\mathscr{0} \\
0 \\
0 \\
0\end{array}$ & $\stackrel{2}{\frac{0}{0}}$ & $\begin{array}{l}\text { B. } \\
\text { के }\end{array}$ & Nָ & $\stackrel{5}{=}$ & 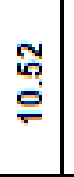 & 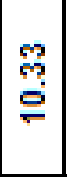 & $\frac{N}{\sigma}$ & ָุ \\
\hline & 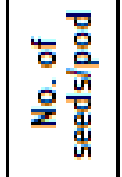 & $\begin{array}{l}\overline{6} \\
6 \\
\stackrel{9}{*}\end{array}$ & 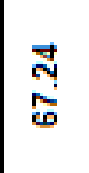 & $\underset{\Xi}{\mp}$ & స్. & 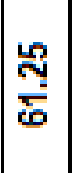 & స్తై & 突 & 触 & 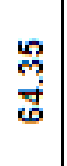 & సุ̣ & 哭 & 产 & సָ & : & $\begin{array}{l}\overline{5} \\
00 \\
6\end{array}$ & ت্ \\
\hline & 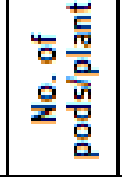 & 总 & $\begin{array}{l}\infty \\
\infty \\
\stackrel{\infty}{\circ}\end{array}$ & 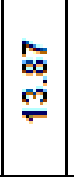 & 욤 & 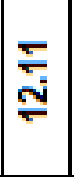 & $\begin{array}{l}\stackrel{ \pm}{\circ} \\
\stackrel{0}{\circ}\end{array}$ & $\begin{array}{l}\overline{0} \\
\stackrel{0}{\circ}\end{array}$ & \begin{tabular}{l}
\multirow{2}{*}{} \\
$\stackrel{6}{\sigma}$
\end{tabular} & $\begin{array}{l}\vec{\Xi} \\
\stackrel{\omega}{\circ}\end{array}$ & $\begin{array}{l}\check{T} \\
\Xi\end{array}$ & $\check{\sigma}^{\circ}$ & 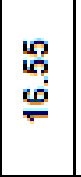 & $\begin{array}{l}\text { ชั } \\
\text { อุ }\end{array}$ & $\overline{\tilde{m}}$ & 苞 & $\stackrel{\text { ஸุ }}{\sim}$ \\
\hline & 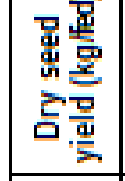 & $\underset{\dot{\sigma}}{\bar{\sigma}}$ & $\underset{\infty}{m}$ & 号 & $\stackrel{\infty}{\stackrel{\infty}{\Sigma}}$ & $\underset{\sigma}{\tilde{N}}$ & 范 & $\begin{array}{l}\stackrel{y}{\vec{j}} \\
\stackrel{\text { ल}}{=}\end{array}$ & $\begin{array}{l}-\dot{j} \\
\dot{\infty} \\
\infty\end{array}$ & 芦 & $\begin{array}{l}\vec{D} \\
\text { on }\end{array}$ & 号 & 옹 & $\stackrel{\Gamma}{\check{\infty}}$ & 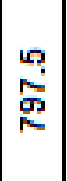 & $\stackrel{m}{\check{r}}$ & में \\
\hline & 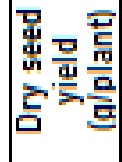 & సे & 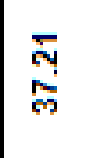 & 岂 & 总 & స్. & స్లి & 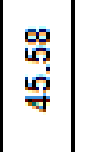 & ヘి & $\begin{array}{l}\vec{\Xi} \\
\vec{j} \\
\vec{j}\end{array}$ & 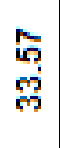 & సี่ & 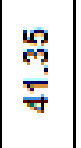 & దิ & స్లి & 芦 & $\frac{ \pm}{i}$ \\
\hline 离 & & 志 & $\begin{array}{l}\vec{\Xi} \\
\sigma\end{array}$ & 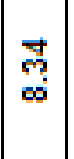 & 总 & $\begin{array}{l}\overline{0} \\
\infty\end{array}$ & 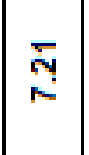 & 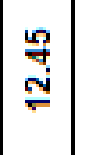 & त़ & $\begin{array}{l}\text { 品 } \\
\sigma \\
\sigma\end{array}$ & $\underset{\infty}{\infty}$ & $\frac{0}{5}$ & 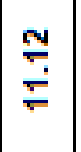 & $\frac{m}{\infty}$ & $\Xi_{\sigma}$ & $\begin{array}{l}\tilde{\infty} \\
\infty \\
\infty\end{array}$ & ָே \\
\hline & 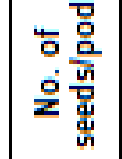 & $\begin{array}{l}\bar{y} \\
\dot{z}\end{array}$ & 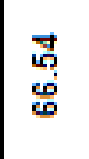 & 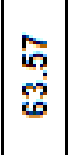 & 产 & गे? & 옳 & กี & 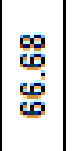 & స్. & 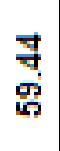 & క్̊ & 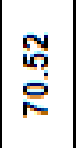 & 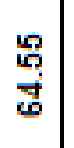 & $\begin{array}{l}\vec{\Xi} \\
\tilde{0} \\
6\end{array}$ & $\begin{array}{l}\overline{5} \\
80 \\
60\end{array}$ & 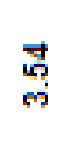 \\
\hline & 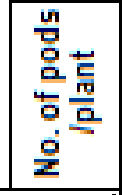 & ঙొ & 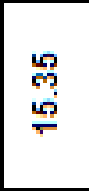 & $\mid \begin{array}{c}\bar{T} \\
\stackrel{\Sigma}{-}\end{array}$ & 兽 & $\stackrel{+}{\stackrel{+}{\sigma}}$ & 꽁 & $\begin{array}{l}\widetilde{\infty} \\
\infty \\
\infty\end{array}$ & 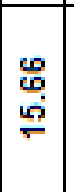 & $\begin{array}{l}\tilde{5} \\
\mathbf{z}\end{array}$ & 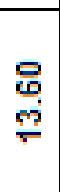 & $\begin{array}{l}\overrightarrow{0} \\
\infty \\
\infty\end{array}$ & 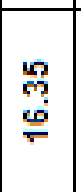 & 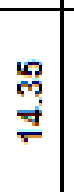 & 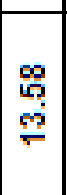 & ָ̊ & 节 \\
\hline & 岂 & 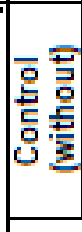 & 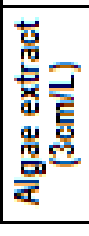 & 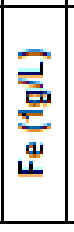 & ప & 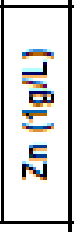 & 을 & 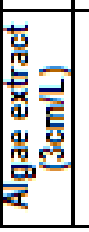 & 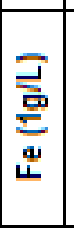 & 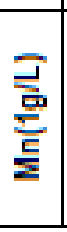 & 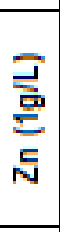 & 을 & 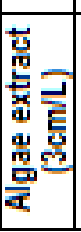 & 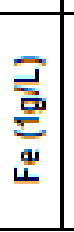 & 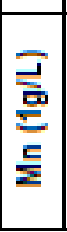 & 莺 & $\begin{array}{l}\text { 总 } \\
\text { 웅 } \\
\text { 呬 } \\
0 .\end{array}$ \\
\hline & & \multicolumn{5}{|c|}{ (" } & \multicolumn{5}{|c|}{ 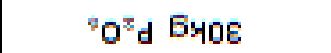 } & \multicolumn{5}{|c|}{${ }^{2} 0^{x} d$ Eyst } & تُ \\
\hline
\end{tabular}




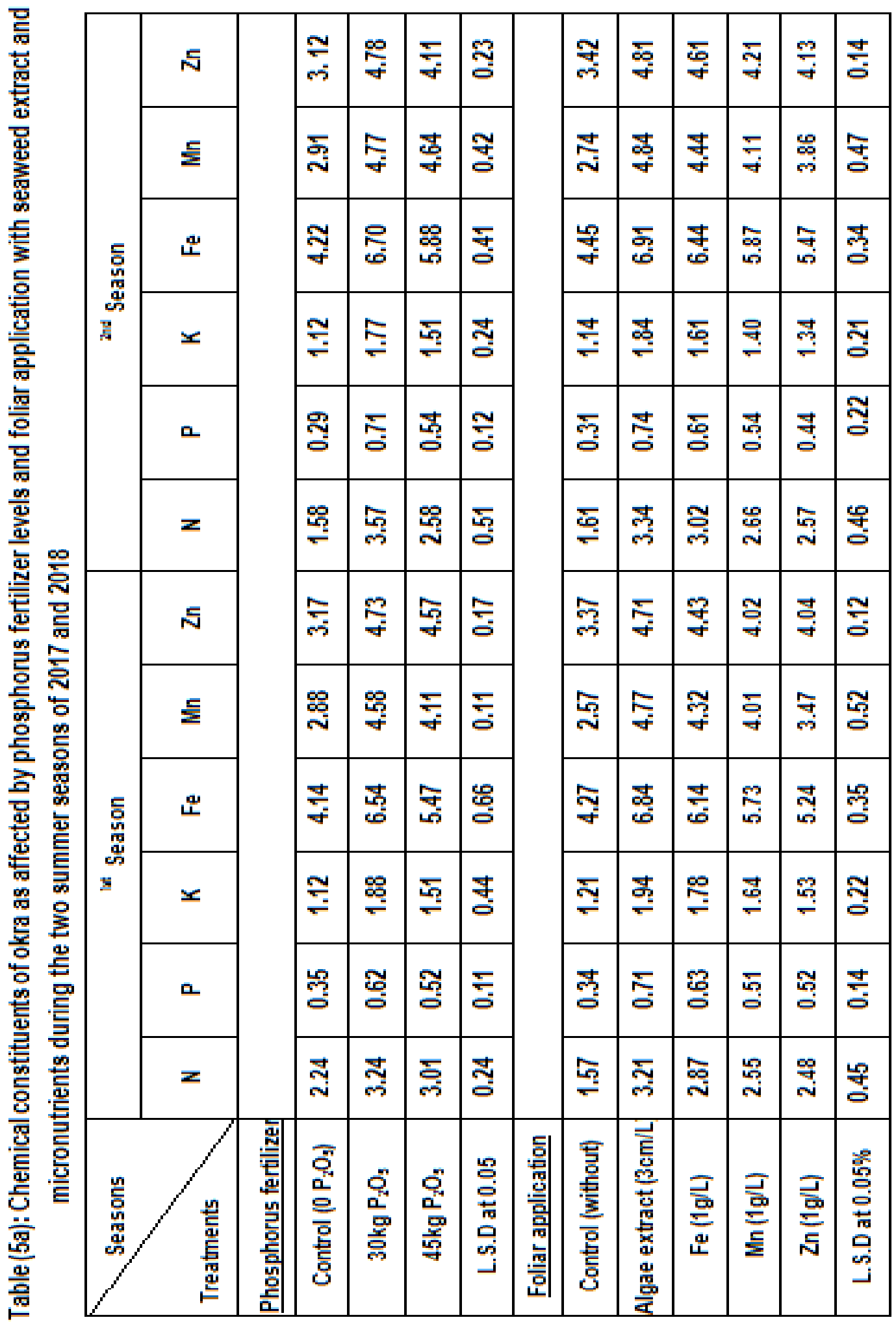




\begin{tabular}{|c|c|c|c|c|c|c|c|c|c|c|c|c|c|c|c|c|c|}
\hline \multirow{6}{*}{ 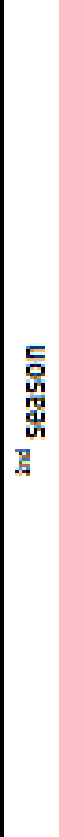 } & กิ & స్ & $\begin{array}{l}\mathscr{\mathscr { g }} \\
\mathbb{8}\end{array}$ & $\frac{5}{8}$ & 承 & 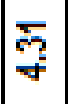 & 䓵 & 号 & $\underset{8}{F}$ & $\begin{array}{l}\tilde{8} \\
\dot{q}\end{array}$ & $\begin{array}{l}\stackrel{8}{0} \\
\dot{8}\end{array}$ & ช్ & $\underset{8}{F}$ & $\begin{array}{l}\widetilde{\Xi} \\
\underset{\sim}{*}\end{array}$ & 等 & $\bar{z}$ & 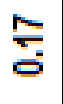 \\
\hline & 들 & চ্] & 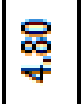 & 赑 & 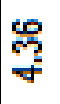 & 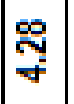 & $\stackrel{\mathscr{N}}{\mathscr{N}}$ & ฐ & $\underset{8}{\mathbb{8}}$ & 栥 & 思 & $\stackrel{\mathscr{B}}{\sim}$ & ס & $\begin{array}{l}\infty \\
\text { 昜 } \\
\end{array}$ & 尔 & $\stackrel{\mathscr{2}}{\underset{\sim}{*}}$ & ন্ \\
\hline & 芒 & శ్ & $\frac{\dot{2}}{\dot{\omega}}$ & 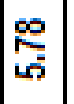 & 曲 & 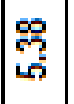 & $\bar{z}$ & 㥐 & 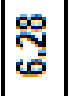 & ஜू & 心్ & 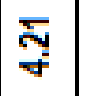 & $\begin{array}{l}0 \\
0.0 \\
00\end{array}$ & 空 & 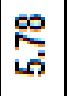 & 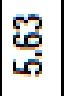 & ్ㅗ \\
\hline & $x$ & $\stackrel{\mathscr{m}}{\stackrel{2}{2}}$ & $\underset{\sim}{\stackrel{2}{=}}$ & $\stackrel{?}{\stackrel{2}{-}}$ & $\stackrel{\leftrightarrow}{\stackrel{\leftrightarrow}{\circ}}$ & 疋 & $\stackrel{g}{=}$ & क़ & $\stackrel{-\infty}{=}$ & 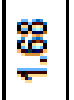 & $\stackrel{8}{\circ}$ & $\stackrel{\text { g }}{=}$ & 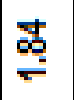 & $\stackrel{?}{\stackrel{2}{2}}$ & $\stackrel{\text { 导 }}{=}$ & $\stackrel{8}{\rightleftarrows}$ & 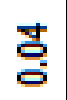 \\
\hline & a & ๙ิ & 点 & 电 & 㞧 & 总 & g & 志 & $\frac{n}{\tilde{O}}$ & ষ্ণ & ষ্ট్: & लू & $\underline{\sigma}$ & 뭉 & ণֶ & 象 & $\underset{ }{\circ}$ \\
\hline & $z$ & $\stackrel{\bar{\sigma}}{=}$ & శ్ & ন্ত & 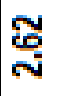 & $\mid \begin{array}{l}\mathscr{8} \\
\stackrel{0}{0}\end{array}$ & $\stackrel{\bar{g}}{=}$ & ড̄ & $\underset{\text { m. }}{\infty}$ & $\bar{\infty}$ & ণ্ণ & $\stackrel{\infty}{\stackrel{\infty}{\rightleftarrows}}$ & 㤐 & $\stackrel{\sim}{\sim}$ & $\stackrel{\circ}{\dddot{g}}$ & 足 & $\underset{ }{ \pm}$ \\
\hline \multirow{6}{*}{$\begin{array}{l}\text { 듬 } \\
\text { 总 } \\
\text { 足 } \\
\text { : }\end{array}$} & స్ & ले & $\underset{\mathcal{F}}{\tilde{q}}$ & $\underset{殳}{\stackrel{?}{q}}$ & ঙี & $\underset{\sim}{\approx}$ & $\underset{m}{m}$ & ఖ & $\underset{\mathbb{z}}{\mathbb{Z}}$ & 戛 & $\begin{array}{l}\text { 足 } \\
\stackrel{8}{8}\end{array}$ & 昌 & $\stackrel{\mathscr{P}}{\tilde{q}}$ & 多 & ஜ্ & $\stackrel{\mathscr{2}}{\stackrel{2}{*}}$ & $\stackrel{m}{5}$ \\
\hline & 돌 & ָூ & $\underset{\dot{8}}{F}$ & $\underset{\mathcal{F}}{\mathcal{F}}$ & ন্ & $\underset{\sim}{\dddot{Z}}$ & $\underset{N}{\mathbb{N}}$ & 㲾 & 岳 & 总 & 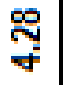 & 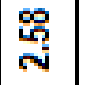 & $\underset{+}{\mathbb{2}}$ & $\underset{\mathcal{F}}{\mathcal{Y}}$ & 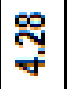 & $\underset{7}{\frac{9}{7}}$ & $\stackrel{\infty}{\circ}$ \\
\hline & ய & ळ్ & 용 & 㦴 & స్ & $\overline{\tilde{m}}$ & $\underset{\sim}{\sim}$ & 志 & $\frac{ \pm}{6}$ & $\left|\begin{array}{l}\Re \\
\\
\end{array}\right|$ & 윰 & $\underset{\dot{g}}{\frac{5}{8}}$ & Øூّ & ర్ & 芯 & 䍐 & $\stackrel{ \pm}{\circ}$ \\
\hline & $x$ & ָุ & $\stackrel{\Sigma}{=}$ & $\stackrel{\circ}{\circ}$ & $\stackrel{\bar{s}}{\stackrel{2}{2}}$ & 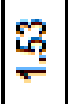 & $\underset{-}{\tau}$ & 帝 & $\stackrel{\infty}{\stackrel{2}{=}}$ & $\stackrel{+}{\circ}$ & $\stackrel{\square}{-}$ & 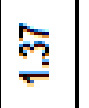 & $\stackrel{\mathscr{\infty}}{\mathscr{\infty}}$ & $\stackrel{\infty}{\circ}$ & 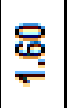 & 总 & $\mathscr{0}$ \\
\hline & $a$ & 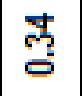 & $\overline{\mathbb{S}_{0}}$ & ஜृ & 동 & 志 & g్ & œ & $\Sigma_{0}$ & ஜ용 & 适 & 容 & 志 & $\mid \begin{array}{l}0 \\
\stackrel{8}{0}\end{array}$ & 怘 & 蒿 & $\frac{m}{5}$ \\
\hline & $z$ & $\stackrel{5}{2}$ & $\overline{\text { } ু ~}$ & $\stackrel{\infty}{\infty}$ & 㞧 & 空 & 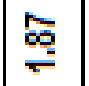 & 亗 & $\underset{m}{\doteqdot}$ & $\underset{\sim}{\stackrel{N}{N}}$ & $\underset{N}{N}$ & 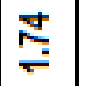 & జ్. & $\begin{array}{l}E \\
\sim\end{array}$ & $\underset{\sim}{\bar{\sigma}}$ & 芯 & Е \\
\hline & 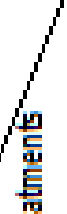 & 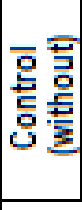 & 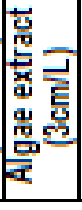 & 惡 & 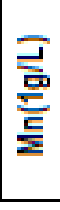 & 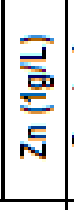 & 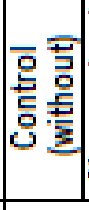 & 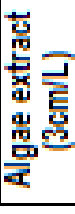 & 惡 & 䔍 & 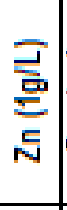 & 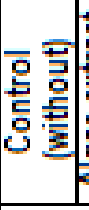 & 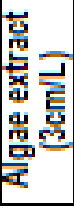 & 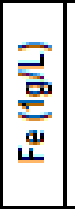 & 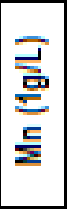 & 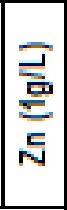 & \multirow{2}{*}{ 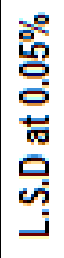 } \\
\hline & & \multicolumn{5}{|c|}{ כ כ } & \multicolumn{5}{|c|}{${ }^{2} O^{x} d$ Бчо } & \multicolumn{5}{|c|}{ 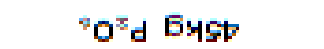 } & \\
\hline
\end{tabular}


Table (6a): Germination ratio (\%), germination rate(days) and sprout length(cm) of okra dry seeds as affected by phosphorus fertilizer levels and foliar application with seaweed extract and micronutrients during the two summer seasons of 2017 and 2018.

\begin{tabular}{|c|c|c|c|c|c|c|}
\hline \multirow{2}{*}{$\begin{array}{l}\text { Seasons } \\
\text { Treatments }\end{array}$} & \multicolumn{3}{|c|}{ 1st season } & \multicolumn{3}{|c|}{ 2nd season } \\
\hline & $\begin{array}{l}\text { Germination } \\
\text { ratio\% }\end{array}$ & $\begin{array}{c}\text { Germination } \\
\text { rate(days) }\end{array}$ & $\begin{array}{c}\text { Sprout } \\
\text { length }(\mathrm{cm})\end{array}$ & $\begin{array}{c}\text { Germination } \\
\text { ratio\% }\end{array}$ & $\begin{array}{c}\text { Germination } \\
\text { rate(days) }\end{array}$ & $\begin{array}{c}\text { Sprout } \\
\text { length }(\mathrm{cm})\end{array}$ \\
\hline \multicolumn{7}{|l|}{$\frac{\text { Phosphorus }}{\text { fertilizer }}$} \\
\hline Cont. $\left(0 \mathrm{P}_{2} \mathrm{O}_{5}\right)$ & 77.9 & 5.47 & 15.4 & 78.7 & 5.22 & 16.1 \\
\hline $30 \mathrm{~kg} \mathrm{P}_{2} \mathrm{O}_{5}$ & 92.5 & 2.51 & 20.1 & 93.5 & 2.31 & 21.3 \\
\hline $45 \mathrm{~kg} \mathrm{P}_{2} \mathrm{O}_{5}$ & 86.1 & 3.47 & 18.3 & 87.1 & 3.24 & 19.4 \\
\hline L.S.D at 0.05 & 4.05 & 0.43 & 1.3 & 3.82 & 0.34 & 2.4 \\
\hline \multicolumn{7}{|l|}{$\begin{array}{c}\text { foliar } \\
\text { application }\end{array}$} \\
\hline $\begin{array}{l}\text { Control } \\
\text { (without) }\end{array}$ & 78.8 & 5.35 & 15.4 & 79.2 & 5.86 & 16.1 \\
\hline $\begin{array}{c}\text { Algae extract } \\
\qquad(3 \mathrm{~cm} / \mathrm{L})\end{array}$ & 92.7 & 2.37 & 21.7 & 93.1 & 2.36 & 22.1 \\
\hline $\mathrm{Fe}(1 \mathrm{~g} / \mathrm{L})$ & 87.8 & 3.47 & 18.3 & 88.2 & 3.54 & 19.5 \\
\hline $\operatorname{Mn}(1 \mathrm{~g} / \mathrm{L})$ & 84.5 & 4.23 & 17.5 & 85.3 & 4.31 & 18.6 \\
\hline $\mathrm{Zn}(1 \mathrm{~g} / \mathrm{L})$ & 83.7 & 4.15 & 16.5 & 84.4 & 4.11 & 17.2 \\
\hline L.S.D at 0.05 & 2.31 & 0.47 & 1.63 & 2.87 & 0.21 & 2.4 \\
\hline
\end{tabular}

As for the influence of foliar spraying on okra seed germination tests with seaweed extract and micronutrients, it can be noticed from the same data Table (6a) that the application of seaweed extract at the rate of $3 \mathrm{~cm} / \mathrm{L}$ followed by Fe at the rate $1 \mathrm{~g} / \mathrm{L}$ gave the highest seed quality as compared with the other treatments or the control. Thus, the stimulation effect of algae extraction on plant growth and seed yield might reflect on seed quality leading to an increase in germination percentage and subsequently seedling criteria. The positive effect of Iron is an important micronutrient for chlorophyll formation, photosynthesis, enzyme systems and respiration of plants (Havlin et al., 1999), which led to increment of seed germination ratio and rate. The obtained results are in harmony with those of Hegazy et al., (2010) on common bean, El- Nahas and Abd El-Azeem (1999) stated that pretreatment of Vicia faba seeds with the extract of Anabaena variabilis induced an increase in germination percentage, root growth, seedling dry weight and soluble proteins as compared with untreated seeds. Ismail (2016) on common bean revealed that adding algae extract at $5 \mathrm{~cm} / \mathrm{L}$ resulted in the highest values of seed germination ratio (\%), germination rate (days), and sprout length $(\mathrm{cm})$.

According to the interaction effect among phosphorus fertilizer levels and foliar application treatments, the results in Table (6b) obviously showed that the highest germination ratio, germination rate, and sprout length were obtained by adding phosphorus fertilizer at the rate of $30 \mathrm{~kg} \mathrm{P}_{2} \mathrm{O}_{5} /$ fed with spraying $3 \mathrm{~cm} / \mathrm{L}$ seaweed extract followed by $\mathrm{Fe}$ at the rate $1 \mathrm{~g} / \mathrm{L}$. as compared with other tested treatments or the control. 
Table (6b): Germination ratio, germination rate and sprout length of okra dry seeds as affected by the interaction between phosphorus fertilizer levels and foliar application with seaweed extract and micronutrients during the two summer seasons of 2017 and 2018.

\begin{tabular}{|c|c|c|c|c|c|c|c|}
\hline \multirow{2}{*}{\multicolumn{2}{|c|}{ Seasons }} & \multicolumn{3}{|c|}{ 1st season } & \multicolumn{3}{|c|}{${ }^{2 n d}$ season } \\
\hline & & \multirow{2}{*}{$\begin{array}{c}\begin{array}{c}\text { Germination } \\
\text { ratio\% }\end{array} \\
76.1\end{array}$} & \multirow{2}{*}{$\begin{array}{c}\text { Germination } \\
\text { rate(days) }\end{array}$} & \multirow{2}{*}{$\begin{array}{c}\begin{array}{c}\text { Sprout } \\
\text { length }(\mathrm{cm})\end{array} \\
15.7\end{array}$} & \multirow{2}{*}{$\begin{array}{c}\begin{array}{c}\text { Germination } \\
\text { ratio\% }\end{array} \\
76.7 \\
\end{array}$} & \multirow{2}{*}{\begin{tabular}{|c|}
$\begin{array}{c}\text { Germination } \\
\text { rate(days) }\end{array}$ \\
5.51
\end{tabular}} & \multirow{2}{*}{\begin{tabular}{|c}
$\begin{array}{c}\text { Sprout } \\
\text { length }(\mathrm{cm})\end{array}$ \\
16.7
\end{tabular}} \\
\hline कृ & $\begin{array}{c}\text { Control } \\
\text { (without) }\end{array}$ & & & & & & \\
\hline o & $\begin{array}{c}\text { Algae extract } \\
(3 \mathrm{~cm} / \mathrm{L})\end{array}$ & 87.4 & 3.22 & 17.7 & 88.0 & 3.24 & 18.7 \\
\hline 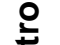 & $\mathrm{Fe}(1 \mathrm{~g} / \mathrm{L})$ & 85.4 & 3.91 & 16.7 & $86 . .3$ & 3.82 & 17.7 \\
\hline & Mn (1g/L) & 83.2 & 4.23 & 16.3 & 83.7 & 4.17 & 17.3 \\
\hline & $\mathrm{Zn}(1 \mathrm{~g} / \mathrm{L})$ & 81.7 & 4.11 & 16.0 & 82.7 & 4.22 & 17.0 \\
\hline \multirow{5}{*}{ 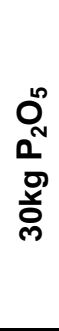 } & $\begin{array}{l}\text { Control } \\
\text { (without) }\end{array}$ & 78.8 & 5.35 & 16.3 & 78.0 & 3.51 & 17.7 \\
\hline & $\begin{array}{c}\text { Algae extract } \\
(3 \mathrm{~cm} / \mathrm{L})\end{array}$ & 92.7 & 2.37 & 21.3 & 93.7 & 2.71 & 22.7 \\
\hline & $\mathrm{Fe}(1 \mathrm{~g} / \mathrm{L})$ & 87.8 & 3.47 & 19.7 & 88.7 & 3.44 & 19.7 \\
\hline & Mn (1g/L) & 84.5 & 4.23 & 18.7 & 85.3 & 4.61 & 18.7 \\
\hline & $\mathrm{Zn}(1 \mathrm{~g} / \mathrm{L})$ & 83.7 & 4.15 & 17.7 & 84.7 & 4.57 & 18.0 \\
\hline \multirow{5}{*}{ 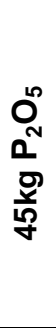 } & $\begin{array}{c}\text { Control } \\
\text { (without) }\end{array}$ & 77.5 & 5.51 & 16.7 & 78.1 & 5.61 & 181 \\
\hline & $\begin{array}{c}\text { Algae extract } \\
(3 \mathrm{~cm} / \mathrm{L})\end{array}$ & 90.7 & 2.71 & 20.8 & 91.7 & 2.63 & 21.3 \\
\hline & $\mathrm{Fe}(1 \mathrm{~g} / \mathrm{L})$ & 86.0 & 3.22 & 18.3 & 88.7 & 3.81 & 19.0 \\
\hline & Mn (1g/L) & 82.7 & 4.66 & 17.3 & 84.7 & 3.94 & 18.3 \\
\hline & $\mathrm{Zn}(1 \mathrm{~g} / \mathrm{L})$ & 82.1 & 4.54 & 17.3 & 83.0 & 3.98 & 18.7 \\
\hline \multicolumn{2}{|c|}{ L.S.D at 0.05} & 3.9 & 1.63 & 1.7 & 3.2 & 0.39 & 24 \\
\hline
\end{tabular}

\section{Conclusion}

The current study showed a general positive impact of phosphorus fertilizer with foliar application of micronutrients or seaweed extract on okra plants cv. Balady. Phosphorus fertilizer at the rate of $30 \mathrm{~kg} \mathrm{P}_{2} \mathrm{O}_{5} / \mathrm{fed}$ with spraying seaweed extract at the rate of $3 \mathrm{~cm} / \mathrm{L}$ resulted the highest values of vegetative growth character, total dry seed yield/fed. and chemical constituents in okra dry seeds.

\section{REFERENCES}

Abbas, S. M. (2013). The influence of biostimulants on the growth and on the biochemical composition of Vicia faba cv. Giza 3 beans. Romanian Biotechnological Letters, 18(2): 80618068.

Abd El-Mawgoud, A.M.R., A.S. Tantawy, M.A. El-Nemr and Y.N. Sassine (2010). Growth and yield responses of strawberry plants to chitosan application. Europ. J. Scientific Res., 39 (1): 161-168.

Abd EL-Moniem, E. A. A. and S. E. AbdAllah (2008). Effect of green algae cells extract as foliar spray on vegetative growth, yield and berries quality of superior grapevines. J. 
Amer. Eur.Agric. and Environ. Sci., (4): 427-433.

Ahmad, I., M. Asif, A. Amjad and S. Ahmad (2011). Fertilization enhances growth, yield and xanthophylls contents of marigold. Turk. J. Agric. For., 35: 641-648.

Ahmad, S., L.H. Akhtar, S. Ahmad, N. Iqbal and M. Nasim (2009). Cotton (Gossypium hirsutum L.) varieties responded differently to foliar applied boron in terms of quality and yield. Soil Environ., 28: 88-92.

Ahmed A., M. Mohsen and M. K. AbdelFattah (2015). Effect of different levels of nitrogen and phosphorus fertilizer in combination with botanical compost on growth and yield of okra (Abelmoschus esculentus L.) under sandy soil conditions in Egypt. Asian Journal of Agricultural Research 9: 249-258.

Amjad, M., A. Muhammed and A. Ali (2001). Effect of phosphorus and planting density on seed production of okra (Abelmoschus esculentus Moench). J. of Agric. Bio. 4: 380 $-383$.

Anna, K., R. Kornas and S. Kocira (2013). Effect assessment of kelpak sl on the bean yield (Phaseolus vulgaris L.). J. of Central European Agriculture, 14(2): 545-554.

Arif, M., S. Ali, A. Shah, N. Javed and A. Rashid (2005). Seed priming maize for improving emergence and seedling growth. Sarhad J. Agric., 21(4): 539543.

Asgedom, H. and M. Becker (2001). Effect of seed priming with nutrient solutions on germination, seedling growth and weed competitiveness of cereals in Eritrea. In: Proc. Deutscher Tropentag, Univ. Bonn and ATSAF, Margraf Publishers Press, Weickersheim. p. 282.
Attememe, J.Y.A. (2009). The effect of humic acid and seaweed extracts on the growth, chemical characteristics of Rosmarinus officinalis L. The $6^{\text {th }}$ scientific conference, Biology Dept., College of Education, University of Tikrit. Plant Sci., 1-17.

Black, C. A. (1965). Methods of soil analysis part I- physical and mineralogical properties. A. S. A. Madison Wise., USA.

Brown, J. D. and O. Lilleland (1946). Rapid determination of potassium and sodium in plant material and soil extracted by flam photometry. Proc. Amer. Soc. Hort. Sci., (48): 341- 346.

Cakmak, I. (2008). Enrichment of cereal grains with zinc: agronomic or genetic biofortification? Plant and Soil, 302: 117.

Chapman, V. J. and D.J. Chapman (1980). Seaweeds and their uses. $3^{\text {rd }}$ ed. Chapman and Hall, USA., pp. 334.

Chattopadhyay, A., S. Dutta1 and S. Chatterjee (2011). Seed yield and quality of okra as influenced by sowing dates. African J. of Biotec., 28: 5461-5467.

Dalia, A. S. Nawar and Sabreen Kh. A. Ibraheim (2014). Effect of algae extract and nitrogen fertilizer rates on growth and productivity of peas. Middle East J. of Agric. Res., 3(4): 1232-1241.

El-Nahas, A.I. and E.A. Abd El-Azeem (1999). Anabaena variabilis as biocontrol agent for salt stressed vicia faba seedlings. J. union Arab Biol., Cairo, 7(B):169-178.

El-Shaikh, K.A. (2005). Effect of phosphorus and potassium fertilization on green yield, seed production and quality of two okra cultivars in reclaimed soils. Assiut $\mathrm{J}$. Agric. Sci., 1: 51- 68.

El-Shaikh, K.A. and M.S. Mohammed (2009). Enhancing fresh and seed yield of okra reducing chemical 
phosphorus fertilizer via using VAMycorrhizal inoculants. World J. Agric. Sci., 5: 810-818.

El-Waraky, Y. B. (2014). Effect of sowing date, plant density and phosphorus fertilization on seed yield of okra. Alex. J. Agric. Res. 59 : 27-41.

Ghasemi, F., R. and A. Ronaghi (2008). Interaction of Iron with Copper, Zinc and Manganese in Wheat as Affected by Iron and Manganese in a Calcareous th Soil. J. Plant Nutr., 31: 839-848.

Gollan, J.R. and J.T. Wright (2006). Limited grazing by native herbivores on the invasive seaweed caulerpa. Taxifolia in a temperate. Australia Estuary Marine and Fresh Water Res., 57(7): 685-694.

Havlin, J.L., J.D. Beaton, S.L. Tisdale and W.L. Nelson (1999). Soil fertility and fertilizers - an introduction to nutrient management 6 Ed. Prentice Hall, New Jersey. Res. J. Agric. and Biol Sci., 4(6): 717-724.

Hegazi, Amal Z., Soha, S. M. Mostafa and H. M. I. Ahmed (2010). Influence of different cyanobacterial application methods on growth and seed production of common bean under various levels of mineral nitrogen fertilization. Nature and Science, 8(11): 183-194.

Ismail, A. Y. (2016). Evaluating the effect of seaweed extracting on plant vegetative growth, dry seed yield and its quality in common bean (Phaseolus Vulgaris L.). Egypt . J. of Appl. Sci., 9: 258-271.

John, M.K. (1970). Colorimeteric determination of phosphoruse in soil plant materials with ascorbic acid. Soil Sci., 109: 214-220.

Khalil, I. A. (2006). Crops and cropping patterns in Pakistan: Crop nutrition. $6^{\text {th }}$ chapter. HEC Publisher, Islamabad. pp. 64-65.
Khattab, E.A., Camilia, Y. EI- Dewiny, M.H. Afifi and R. K. M. Khalifa (2015). Response of some varieties of faba bean to yeast and algae and their impact on yield and its components. Middle East J. of Agric. Res., (4): 907913.

Latique, S., H. Chernane and M. El Kaoua (2013). Seaweed liquid fertilizer effect on physiological and biochemical parameters of bean plant (Phaesolus vulgaris L.) under hydroponic system. European Sci. J. edition (9): 174-191.

Lindsay, W.L. and W. A. Norvell (1978). Development of a DTPA micronutrient soil tests for zinc, iron, manganese, and copper. Soil Sci. Soc. Amer. J. 42:421-428.

Lopez, R.; F. Cabrera.; E. Madejan.; F. Sancho and M. Alvares (2008). Urban compost as an alternative for peat in forestry nursery growing media. Dynamic soil. Dynamic plant, 1: 60-66.

Marrez, D. A., M. M. Naguib, Y. Y. Sultan, Z. Y. Daw and A. M. Higazy (2014). Evaluation of chemical composition for Spirulina platensis in different culture media. Res.J. Pharmaceutical, Biol. and Chem. Sci., 5: 1161-1171.

Mohamed S., B. Dalia, A. H. Selim, Rania M.A. Nassar and Azza M. Salama (2016). Influence of foliar spray with seaweed extract on growth, yield and its quality, profile of protein pattern and anatomical structure of chickpea plant (Cicer arietinum L.). Middle East J. of Applied Sci., 6: 207-221.

Murphy, J. and J.P. Riely (1962). A modified single solution method for determination of phosphate in natural. Anal. Chim. Acta., 29:31-36.

Ohlrogge, A.J. (1962). Some soil- root plant relationships. Soil. Sci.:30-93.

Page, A.L., R.H. Miller and D.R. Keeney (1982). Methods of soil analysis part2: chemical and microbiological properties second edition. Agronomy 
920 Am. Soc. Agron. Inc. Soil Sci. Soc. Am. Inc. Pub. Madison, Wisconsin, USA.

Patton, W., A. Sema and C. Maiti (2002). Effect of different levels of nitrogen and phosphorus on growth, flowering and yield of okra cv. Arka Anamika grown under the foothills. Hort. J., 1: 81-88.

Piper, G. S. (1947). Soil and plant analysis. interscience publishers, Inc. New York. 368 P.

Pregl, F. (1945). Quantitative Organic Micro Analysis. 4 ${ }^{\text {th }}$, Ed. J. Churchill Ltd. London.

Putra, E.T.S., W. Zakaria, N.A.P. Abdullah and G.B. Saleh (2012). Stomatal morphology, conductance and transpiration of Musa sp. cv. Rastali in relation to magnesium, boron and silicon availability. Amer. J. Plant Phys., 7: 84-96.

Rab, A. and I. Haqm (2012). Foliar application of calcium chloride and borax influences plant growth, yield and quality of tomato (Lycopersicon esculentum Mill.) fruit. Turk. J. Agric. For., 36: 695-701.

Rashid, A. and J. Ryan (2004). Micronutrients constraints to crop production in soils with mediterranean type characteristics: A review. J Plant Nutr., 27: 959-975.

Sajid, M., M. A. Khan, A. Rab, S. N. M. Shah, M. Arif, I. Jan, Z. Hussain and M. Mukhtiar (2012). Impact of nitrogen and phosphorus on seed yield and yield components of okra cultivars. j. of animal and plant sci., 3:704-707.

Sathya, B., H. Indu, R. Seenivasan and S. Geetha (2010). Influence of seaweed liquid fertilizer on the growth and biochemical composition of legume crop, Cajanus cajan (L.) Mill sp. J. Phytology, 2 (5): 50-63.

Shkolnik, M.Y. (1984). Trace Elements in Plants. Elsevier, Amsterdam.

Singh, R.V. (2002). Effect of intercrop and $\mathbf{N}$, $\mathbf{P}$ fertilization on performance of okra (Abelmoschus esculentus (L). Moench.). J. Res., Birsa Agric. Univ., 1: 41-44.

Snedecor, G.W. and W.G. Cochran (1990). Statistical methods. 7th Ed. lowa State Univ. Press. Ames., lowa, USA, p. 593.

Tensingh, B. N., L. S. Priyatharsini and V. Raja (2017). Beneficial effect of sargassum weightier on the growth and biochemical characteristics of okra. international j. of recent sci. research., 8: 19787-19792.

Tisdale, S. and W. L. Nelson. (1975). Soil fertility and fertilizers. Macmillan. Publ. co. Inc. New York, 694pp.

Torun, A., I.G.Ã. Itekin, M. Kalayci, A. Yilmaz, S. Eker and I. Cakmak (2001). Effects of zinc fertilization on grain yield and shoot concentrations of zinc, boron and phosphorus of 25 wheat cultivars grown on a zincdeficient and boron-toxic soil. J. Plant Nut., 2: 1817-1829.

Uddin, M.J., M. H. Akand, S. Islam, H. Mehraj1 and A.F.M. Jamal (2014). Phosphorus levels on growth and yield of okra (Abelmoschus esculentus). Bangladesh Research Publications J.,10: 120-124.

Vyomendra, C., Kumar N. (2016). Effect of Algal Bio-fertilizer on the Vigna radiata: A Critical Review. J. of Engineering Res. and Applications, 6 (2):85-94. 
تأثير التسميد الفوسفاتي والرش الورقي بمستخلص الطحالب البحرية والعناصر الصغرى على النمو الخضرى و المحصول البذري للباميا

اثرف يحي اسماعيل ، عادل ابو الاسعاد محمد فايد

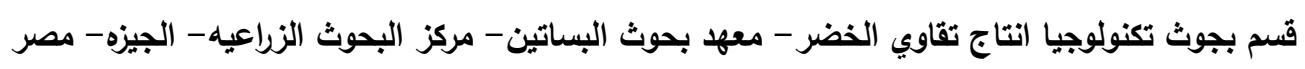

الملخص العربى

اجريت هذه التجربه بمنطقة سيدي سالم بمحافظه كفرالثيخ - جمهوريه مصر العربية خلال الموسمين الصيفين

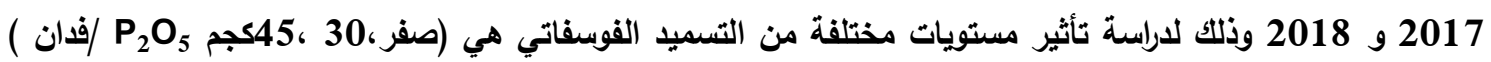
بالتداخل مع الرش الورقي بمستخلص الطحالب بمعل 3سم/2017 لتر والعناصر الصغري وهي الحديد و المنجنيز والزتكك بمعدل 1جم/لتر لكل منها علي النمو الخضري والمحصول البذري الجاف ومكوناته وكذا المحتوي الكيميائي لنباتات الباميه

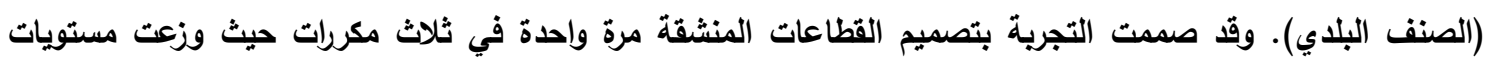

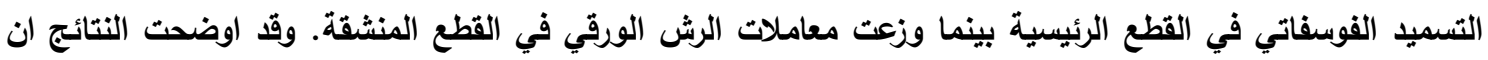

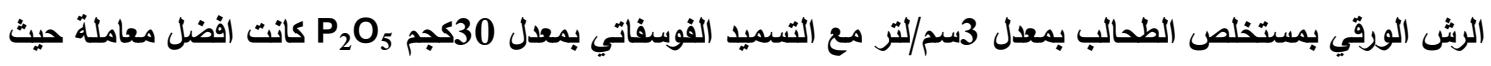
ادت للحصول علي اعلى قيم للنمو الخضري والمحصول البذري الجاف ومكوناته وكذا المحتوي الكيميائي لبناتات الباميه متبوعا بالرش الورقي بالحديد بمعدل 1 جم/ لتر. 